\title{
Current Status and Problems of Legal Regulation of Urgent Search in Criminal Cases
}

\author{
Igor A. Medvedev* \\ Siberian Institute of Law \\ Federal Drug Control Service of Russia (Krasnoyarsk) \\ 20 Rokossovskogo Str., Krasnoyarsk, 660131, Russia
}

Received 18.07.2015, received in revised form 21.09.2015, accepted 20.12.2015

The article notes the relevance and incompleteness of the study by the lawyers and criminalists of the issues of urgent searches. It examines the state of the current legislation on the search procedures, including urgent searches taking into account the hierarchy of the Russian legislation system. The article also sets the problems of legal regulation of urgent search and justifies the necessity of the independent regulatory actions of this type of search. It specifies the interrelation between the criminal procedure and the operational-search activity during the urgent search, which must be balanced at the legislative level. Moreover, we analyzed possible options for legal regulation of the urgent search: departmental and interdepartmental regulatory of the urgent search order. For the purpose of longterm development of the study of search, we propose to systematize the rules regulating the search activity into a single legal act: the federal law on search including the rules providing for the grounds, conditions and procedure for the urgent search.

Keywords: urgent search, legal regulation, operational-search activity, criminal procedure legislation, search activities, departmental and interdepartmental instructions.

DOI: 10.17516/1997-1370-2016-9-1-218-228.

Research area: law.

\section{Introduction \\ into the problem}

The current state of the legal regulation of search is characterized by imperfection of normative regulation of this sphere of activity because of its divergence, fragmentation and inconsistency of regulatory provisions that often do not take into account the nature of the ongoing search activities. At search in the prescribed manner unreasonably much time is spent on planning, execution of tasks and coordination with regulatory permissive authorities for search activities. And given the high degree of organization and equipment, the mobility of the modern criminality leads to low efficiency and lack of results in the implementation of search. Situations requiring the urgent search remain legally unregulated, and in such cases the use of existing legislation on taking search measures can lead to a negative result and non-accomplishment

(c) Siberian Federal University. All rights reserved

* Corresponding author E-mail address: onrio@sibli.ru 
of the search objectives. Whether a crime is solved or not often depends on the timeliness, quickness and urgency of the search.

\section{Grounds of the study, setting of the problem, conception}

The legal regulation of urgent search is inextricably linked with the organization of the search activity in general. Legal regulation of the search activity is a legislatively regulated process of setting and detection of a search object in connection with the committed offense. Collection, study and use of information are a major problem of the legal regulation of the search activity. Since the research is based on the idea that the concepts of the "operational-search activity" and the "search" are not identical, the latter is a broader and independent area of activity involving not only search operations, but also the procedural and organizational-tactical actions. In this case, the legal regulation of search under the operational-search legislation is partial. Thus, the Art.4 of the Federal Law on the OSA stipulates the legal basis for operational-search activity, which consists of the Constitution of the Russian Federation, the Federal Law on the OSA, other federal laws and other normative legal acts of the federal authorities adopted in accordance with them. It also determines that the bodies carrying out the operational-search activity within their powers in accordance with the legislation of the Russian Federation shall accept regulations governing the organization and tactics of search operations. However, the legal basis of the operative-search activity does not include the rules of international law and international treaties ratified by the Russian Federation, which is a significant gap in the international and inter-state search. Grounds and conditions of search, including the urgent one, are not prescribed in the legislation. The Art.7, 8 of the Federal Law on the OSA indicates grounds and conditions of the operative-search measures (hereinafter-OSM) that only partially regulate the search activity.

The criminal procedure legislation fragmentarily presents legal regulation of the urgent search in the procedure of urgent investigative actions and the necessary operational-search measures carried out by an investigator and an inquiry body respectively. The regulatory provisions are prescribed in P. 19, 38 Art.5, Art.157, 210 of the Code of Criminal Procedure of the Russian Federation, defining the concept of search measures, the grounds of urgent investigative actions and the search of a suspect.

Legal scholars have repeatedly proposed to legislate the concept of search. The proposal was made by R.S. Belkin, T.V. Bogoliubskaia, A.A. Zakatov, E.F. Konovalov and others. Currently, P.38 Art.5 of the Code of Criminal Procedure of the Russian Federation regulates the concept of search measures that are defined as "measures taken by an investigator and a body of inquiry on behalf of an inquirer or an investigator to determine a person suspected of committing a crime". However, this concept, like any other definition, does not reflect all the features of the defined concept, and there is no need to formulate them at the legislative level. ${ }^{1}$

Let us consider the current situation of the legislative regulation of search activity depending on the hierarchy of legal acts by their legal force, highlighting the appropriate levels, at which the search activity is regulated.

A. Constitutional level. The articles of the Constitution of the Russian Federation do not regulate the search activity, but it contains the key principles of the search organization as a form of the state activity (Art. 2, 10, 15, 22, 23, 25, 27, 32, 71, 72, etc. of the Constitution of the Russian Federation). Thus, the Constitution of the Russian Federation occupies a central place in the 
system of legal acts regulating the search activity defining its place and role in the system of the executive bodies of the state power.

B. International legal level includes normative legal acts (conventions, agreements, contracts and others) ratified by the Russian Federation. The legal framework for the international and inter-state search is regulated at the international level. At the moment, the Russian Federation has concluded 50 multilateral treaties (conventions) $)^{2}$, aimed at combating certain types of crimes ${ }^{3}$. Despite the fact that the search is not mentioned in the Conventions as the legal means of establishing and ensuring the extradition of persons suspected (accused) of a crime, the procedure for extradition is well determined. For example, the Art.16 of the 2000 UN Convention against Transnational Organized Crime ${ }^{4}$ indicates that states should take measures to ensure the extradition proceedings. And in case the perpetrator's escape the only way of it is search. ${ }^{5}$

C. Legislative level includes normative legal acts adopted by the supreme legislative bodies of the Russian Federation.

The legislative acts constituting the legal basis for the search activities primarily include the Federal Law on the OSA, the Code of Criminal Procedure, and the Federal Law on Police. Thus, in the Art. 2 of the Federal Law on the OSA the search is included in the circle of the main tasks of the operational-search activity; the Art.6 has an exhaustive list of operational search measures permissible for use during search; the Art.7, 8 set the grounds and conditions of their fulfilment, regulate some organizational and tactical aspects of the search activity, including the urgent search.

An important component of the legal regulation of the search activity is a criminalprocedural legislation that establishes the concepts of the search measures, the results of the operational-search activity and contains the possibility of their use in proof, as grounds of search for those suspects who fled from prosecution, and define the basic powers of the search subjects (P. 36.1, 38 of the Art. 5, Art. 89, 210, 238 and 253 of the Code of Criminal Procedure of the Russian Federation).

The search as the main area of activity is established in the laws regulating the activities of the law enforcement agencies, for example, P.4 of Art.2 of the Federal Law "On Police". In some cases, when there are no rules at the legislative level, subordinate legislation regulating the activities of the law enforcement agencies set competences that include a variety of functions, including those for search. Thus, in P.8 of Art.8 of the Provision on the Federal Drug Control Service of the Russian Federation ${ }^{7}$ the drug control authorities are vested with the organization and implementation of search for persons who are accused or suspected of crimes falling within the jurisdiction of these bodies, and who have fled from the bodies of the preliminary investigation or trial or their whereabouts are unknown.

D. Substatutory level regulates certain directions and organization order of the search activity. The normative-legal acts of the substatutory level include the Presidential Decrees, Decisions of the Government of the Russian Federation, inter-ministerial, departmental orders and instructions regulating issues of organization and tactics of the search. The main ones are the inter-departmental instructions on how to submit the results of the operational-search activity to an inquiry body, an investigator or court ${ }^{8}$, Instruction on the order of carrying out overt operational-search inspection of premises, buildings, structures, grounds and vehicles by law-enforcement officers of the Russian Federation and the list of lawenforcement officials of the Russian Federation authorized to issue instructions about carrying out 
overt operational-search inspection of premises, buildings, structures, grounds and vehicles?.

Also, the substatutory legal acts at the state and departmental level regulate the order of the interstate and international search: Presidential Decrees ${ }^{10}$, interdepartmental and departmental orders, instructions and provisions. For example, an interdepartmental instruction on the organization of the information support for cooperation with the Interpol ${ }^{11}$, the Instruction on the organization of information support for cooperation with the Interpol ${ }^{12}$.

In addition, the majority of the substatutory legal acts that directly regulate the issues of covert search activity traditionally refer to secret departmental normative sources (orders, instructions, etc.), which are only mentioned in the public filings.

E. Decisions of the higher judicial bodies can also acquire the features of a normative nature as a result of generalization of judicial practice. Thus, the decisions of the Constitutional Court of the Russian Federation set the regulatory rules considering the provisions of the normativelegal acts with respect to the conformity with the Constitution of the Russian Federation, and are obligatory.

\section{Discussion}

Given the above, it should be stated that the urgent search as an independent type of the search activity, in fact, is not regulated the Russian legislation. However, in our opinion, it is theoretically justified and practically necessary to legislatively formulate the concept, grounds and conditions for its implementation, and to regulate the organization and order of procedure at the substatutory level.

The content of the legal regulation of the urgent search as a legally regulated process should be in the exclusive procedure of the establishment and detection of the search object in extreme circumstances, when delay may result in a serious or especially serious crime, or when there is evidence of a threat to the state, military, economic or ecological security of the Russian Federation. The exclusivity of the procedure of collecting and research of the information about the sought-for object, the procedure for its use during the urgent search is the subject of legal regulation of the urgent search institute in the search activity system, it is objectively subjected by the necessity to urgently conduct search measures and to use the received information in the course of proof in a criminal case.

At the urgent search the issues of organization of interaction of the search subjects should be subject to mandatory regulation. Common grounds for interaction of the preliminary investigation bodies and inquiry bodies engaged in the operational-search measures are defined in legal (Art. 38, 40, 144, 146, 157, 163, 164 and 210 of the Criminal Procedure Code of the Russian Federation, Art. 7, 8, 11 of the Federal Law on the OSA) and substatutory legal acts (mostly these are secret departmental orders). However, currently there is no single normativelegal act (interdepartmental order) that regulates the interaction between all subjects of the search activities, including in situations requiring the urgent search. Currently, each state body performing the search activity accepts and uses its own departmental normative-legal acts that take into account the specifics of organization of search with only departmental orientation. Lack of coordination between various departmental normative acts makes it difficult to carry out joint search activities and makes it almost impossible for the interdepartmental cooperation at the urgent search. In theory, two solutions are offered: unification of the departmental normative legal acts regulating the interaction of subjects of search, or the adoption of a unified interdepartmental normative legal act (order) that 
will bring into force the instruction defining the procedure for interaction in the search activities, including the urgent search.

Therefore, the legal regulation of interaction between the subjects of the urgent search must be based on evidence of the relation of the legislation in the sphere of the operational-search activity and the criminal procedural legislation, since this type of activity must be timely, joint and coordinated between the search subjects. Firstly, this is due to the fact that the information obtained through operational-search measures create preconditions (reasons and grounds) for instituting criminal proceedings (Art. 143 of the Code of Criminal Procedure of the Russian Federation); secondly, at the urgent search, for example when establishing an offender in hiding, the results obtained during the search operations may be used in the crime investigation process (Art. 11 of the Federal Law on the OSA, Art. 89 of the Code of Criminal Procedure of the Russian Federation); thirdly, for certain search operations it is necessary to obtain permission of the court (Articles 23, 25 of the Russian Constitution, Art. 8 of the Federal Law on the OSA), since they may restrict the legitimate rights and interests of citizens. Therefore, under the ratio of regulations of the criminal procedural legislation and regulations in the field of the operational-search activity, we come up with a question on the relation of the criminal procedure and the operational-search activity.

Quite often, in theory they take as a basis a judgment that these activities are also independent in practice in the legal field. However, despite the differences in objectives, methods, means and ways of implementation of these activities, as well as the sources of the legal regulation, it is clear that the purpose of the operationalsearch and the criminal procedure activity is detection of a crime, and at the urgent search the activity is aimed at the specific objective that is establishment and detection of sought- for objects. This is confirmed by the historical development of the legal procedure in Russia, when for a long time there was such a form as a search process; the last attempt to combine the search and investigation activities was made in the 20 's of the last century. ${ }^{13}$ It is not surprising, since the separation of the criminal procedure and the operational-search functions reduces the efficiency of not only search, but also the whole process of criminal investigation, because these activities supplement each other quite naturally. ${ }^{14}$

Indirectly, it can be seen in the purpose of the criminal proceedings through its prescription referred to in Art. 6 of the Code of Criminal Procedure of the Russian Federation: "protection of rights and legitimate interests of individuals and organizations that became victims of crime; protection of individuals from illegal and groundless accusation, conviction and restriction of rights and freedoms and the criminal prosecution and infliction of just punishment", as well as for the operational-search measures (Art. 1 of the Federal Law on the OSA) that are held "to protect the life, health, rights and freedoms of a person and a citizen, property, to provide security for society and state from criminal attacks".

Thus, the legal sources, according to which the urgent search should be carried out (Code of Criminal Procedure and the Federal Law on the OSA), define the purpose and objectives of the criminal procedure and the operatively-search activity based on the state of security of a person, his rights and freedoms from criminal attacks. In addition, the urgent search as a kind of the search activity has a close relation and interdependence of the activities and their focus on a single result, which is establishment and detection of the soughtfor object and the following detection of a crime. In most cases, the operational search (observation control) held before institution of a criminal case and establishment or determination of the location of the sought-for object is essentially the 
urgent search that, in future, may continue during investigation of the criminal case.

Interconnection of the criminal-procedure and the operational-search activities should be balanced at the legislative level and enable to freely use the results of the operational-search measures in the criminal proceedings, taking into account the requirements for evidence that is established by the criminal-procedure legislation. Therefore, in theory there were proposals to expand the list of evidence under Part 2 of Art. 74 of the Code of Criminal Procedure of the Russian Federation, which is currently exhaustive, and thus to create conditions for the use of the information (including orienting) received during the operational-search activity. ${ }^{15}$

Modern views on the search activity, including in the framework of the urgent search and the use of its results obtained by carrying out operationalsearch measures in the criminal proceedings, are mostly associated with the operationalsearch legislation and normative legal acts of the interdepartmental ${ }^{16}$ and departmental level, which prescribe directions and order of their use.

Most scholars pointing to a non-procedural form of operational-search measures determine their belonging to the operational-search legislation. However, the criminal procedure law contains a provision on the use of the results of the operational-search activity in proving (Art. 89 of the Code of Criminal Procedure of the Russian Federation), which should be supplemented by provisions on the grounds of using of the results of the OSA indicating the demands made on them, for example the authenticity of the information provided, regardless of whether the source is specified or not. Also, we should take into account such areas of the use of the results of the operational-search activity, as the use as grounds and reasons for criminal proceedings or for the preparation and implementation of investigative and judicial actions, in the order prescribed by the
Code of Criminal Procedure. In this connection, it is advisable to change the name of the Art. 89 of the Code of Criminal Procedure "Use of the results of the operational-search activity" and expand the content of the regulation with all areas of use of the results of the operational-search activity obtained in accordance with the Federal Law on the OSA. This transformation of the regulation will strengthen the role and independence of an inquiry body in carrying out urgent search, as well as will help to achieve goals faster and more effectively.

The theory of the operational-search activity includes the idea of separation of the procedural part of the search activity and providing a legislative framework for it. A.Iu. Shumilov proposes to include the provisions regulating the operational-search activity into the Code of Criminal Procedure of the Russian Federation. ${ }^{17}$ M.P. Poliakov proposes to introduce a category of the "criminal-search process" giving the operational-search activity a procedural form and thereby solve the question of proof when using the results of the OSA to investigate criminal cases. $^{18}$ T.A. Tkachuk believes that the current system of legal support of search and practice of its implementation need to develop a unified model of the normative-legal regulation of search. Such a model may include the normativelegal regulation of organization of scientific and technical, power, operational-search and preventive support of search. Components of the unified model of the normative-legal regulation of search should reflect the typical connections of the search activity, its functional subsystems and specificity of search at various stages of investigation proceedings. ${ }^{19}$ V.F. Lugovik offers the concept of an "operational-search right" with the development of the "operational-search code" 20 that, apparently, should cover the procedural part of the operational-search activity and regulate the urgent search as well. 
Given the current positions of scientists we should focus on the fact that the search activity system should include a legally-regulated complex (list) of search means that include operational-search measures, investigatory actions and some organizational and tactical measures.

\section{Conclusion}

Efficient organization of the urgent search depends on the order and consistency of the legal regulation of the search activity in general. Urgent search should be aimed at early detection and prevention of grave and especially grave crimes and acquisition of immediate and evidentiary information about the sought-for object, allowing their identification when detected both in normal and extreme conditions.

It is clear that the legal basis for the search activity should be based on the greater autonomy of an inquiry body during the urgent search, since it is necessary to let it not only carry out operational-search measures and other search actions, including proceedings at request of an investigator, but also independently carry out urgent search in the presence of grounds and conditions clearly defined by law.

Given the above, in the framework of the criminal procedure legislation, the urgent search may be settled by:

1) legislative consolidation of the grounds and conditions of search conducted in the urgent manner;

2) legislative regulation of an orderly and consistent system of means of the urgent search (investigatory actions, operational-search and other measures), and at the substatutory level the order of their application;
3) concretization of the provisions of Art.89 of the Code of Criminal Procedure of the Russian Federation on the use of results of the operationalsearch activity.

Legal regulation of the urgent search in the operational-search legislation should be based on the regulation of the search system as a whole, where the urgent search will act as a subsystem with legislatively prescribed grounds, conditions and a complex (list) of means. However, under the current legislative system it is hardly possible, since a complex of means (measures, actions) that can be used in the search activity is much broader (by the subject of regulation) than a complex of means used in the operational-search activity, and thus it cannot be formulated within the same branch of legislation and requires independent regulation in related areas of law, which, unfortunately, makes the law enforcement practice of search less effective. In addition, there are urgent search measures that are not regulated by law at all, for example, the ambush and tracing.

For the purpose of long-term development of search as a separate kind of the law enforcement activity it is advisable to legally regulate this area as independent beyond the considered branches of legislation, which means to develop a federal law on search that will include provisions regulating implementation of the urgent search. As part of an alternative solution, it is possible to provide a detailed study of provisions on the urgent search in the framework of the existing legislation (criminal-procedure, operational-search) and to develop an interdepartmental instruction on the organization and order of the urgent search at the substatutory level.

\footnotetext{
Lugovik V.F. Codification as the way of improvement of legal regulation of operational-search activity. Operativnik (syshchik), 2015. 1(42), January, P.17.

2 See, for example: the Convention on legal assistance and legal relations in civil, family and criminal cases (concluded in Minsk on January 22, 1993, entered into force on May 19, 1994, for the Russian Federation - December 10, 1994); The
} 
list of officially published international treaties of the Russian Federation providing for the opportunity to extradition for prosecution, execution of a sentence, and transfer of a person sentenced to imprisonment to serve his sentence in a state of which such person is a citizen, extradition of a person to a foreign state for the purpose of criminal prosecution or execution of a sentence: Annex to the Resolution of the Plenum of the Supreme Court of the Russian Federation of June 14, 2012 No.11 "On the practice of courts to consider issues relating to the extradition of persons for criminal prosecution or execution of sentence, as well as the transfer of persons to serve their sentences".

3 See, for example: United Nations Convention against Illicit Traffic in Narcotic Drugs and Psychotropic Substances (concluded in Vienna on December 20, 1988, ratified by the Decree of the Supreme Soviet of the USSR from October 9, 1990 No. 1711-I) SPS KonsultantPlus.

4 The Convention against Transnational Organized Crime adopted in New York on November 15, 2000 by the Resolution $55 / 25$ at the 62 nd plenary meeting of the 55th session of the UN General Assembly. SPS KonsultantPlus.

5 Gasymov N.G. International search: Theory and Practice: PhD thesis in Law: 12.00.09. Gasymov Niyazi Gara oglu [defence place: The Academy of Management of the Interior Ministry of Russia]. Moscow, 2005, P. 5.

6 On Police: Federal Law of February 7, 2011 No.3-FZ. SPS KonlsultantPlus.

7 The provision on the Federal Drug Control Service of the Russian Federation approved by the Decree of the Russian President of July 28, 2004 No.976 “The Issues of Federal Drug Control Service of the Russian Federation”. SPS KonlsultantPlus.

8 On the approval of the Instruction about an order of representation of results of the operational-search activity to an inquiry body, investigator or court: Order of the Ministry of Internal Affairs of Russia No.776, Ministry of Defence of Russia No.703, FSS of Russia No.509, FSGS of Russia No.507, FCS of Russia No.1820, EIS of Russia No.42, FSIN of Russia No.535, FDCS of Russia No.398, Investigation Committee of Russia No.68 of September 27, 2013. Rossiyskaia gazeta, No.282, December 13, 2013.

9 On the approval of the Instruction on the order of carrying out overt operational-search inspection of premises, buildings, structures, grounds and vehicles by law-enforcement officers of the Russian Federation and the list of law-enforcement officials of the Russian Federation authorized to issue instructions about carrying out overt operational-search inspection of premises, buildings, structures, grounds and vehicles: Order of the Ministry of Internal Affairs of Russia of April 1, 2014 No.199. SPS KonsultantPlus.

10 On participation of the Russian Federation in the activities of International Criminal Police Organization - the Interpol: Decree of the President of the Russian Federation of 30.07.1996 No.1113. SPS KonsultantPlus.

11 On the approval of the Instruction on the organization of information support for cooperation with the Interpol: Order of the Ministry of Internal Affairs of the Russian Federation No.786, Ministry of Justice of the Russian Federation No.310, FSS of the Russian Federation No.470, FSO of the Russian Federation No.454, FDCS of the Russian Federation No.333, FCS of Russia 971 of 06.10 .2006 . SPS KonsultantPlus.

12 On measures for improvement of cooperation with the Interpol: The order of the Ministry of Internal Affairs of the Russian Federation of 28.02.2000 No.221, the Instruction of the organization of information support for cooperation with the Interpol. SPS KonsultantPlus.

13 All-Russian Congress of leaders of Soviet justice: the verbatim report. M: publishing house for legal literature of the People's Commissariat of the RSFSR, 1924. P.36.

14 See: Bazhanov S.V. Correlation of criminal procedural and operational-search powers of the staff of law enforcement bodies (police). Operativnik (syshchik), 2014. No.3(39), P.51. Poliakov M.P. The basics of criminal procedure interpretation of results of the operational-search activity. Nizhny Novgorod: Ministry of Internal Affairs of Russia, 2000. P.59-67.

15 Korenevskiy Iu.V. Actual problems of proving in a criminal process. State and right, 1999, No.2, P.61.

16 On the approval of the Instruction about an order of representation of results of operational search activity to the inquiry bodies, investigator or court: Order of the Ministry of Internal Affairs of Russia No. 776, Ministry of Defence of the Russian Federation No. 703, FSS of Russia No. 509, FSO of Russia No. 507, FCS of Russia No. 1820, SVR of Russia No. 42, FSIN of Russia No. 535, FSKN of Russia No. 398, SK of Russia No. 68 of 27.09.2013. Rossiyskaia gazeta, No.282, 13.12.2013.

17 Shumilov A.Iu. Operational-search science in Russia in the Post-Soviet time (1992-2012): periodization, staged state and expected development directions. Operativnik (syshchik), 2013 No.3 (36), July, P.12.

18 Poliakov M.P. Criminal procedure interpretation of results of operational-search activity: abstract of a PhD thesis in Legal Sciences. Nizhny Novgorod: Nizhny Novgorod Law Institute of the Ministry of Internal Affairs of Russia, 2002.

19 Tkachuk T.A. Op. cit. P.51

20 Lugovik V.F. Op. cit. 14-15

\section{References}

Bazhanov S.V. (2014). Correlation of criminal procedural and operational search powers of the staff of law enforcement bodies (police). Operativnik (syshchik), 3(39), 51-54.

Vserossiyskiy sezd deiateley sovetskoy iustitsii: stenograficheskiy otchet [All-Russian congress of the figures of Soviet justice: verbatim record]. Moscow, Yurid. izd-vo Narkomyusta RSFSR, 1924. $36 \mathrm{p}$. 
Gasymov N.G. Mezhdunarodnyi rozysk: voprosy teorii i praktiki: avtoref. diss. [International search: the issues of theory and practice: abstract of a thesis]. Moscow: Akademija upravlenija MVD Rossii, 2005. 49 p.

Konventsiia o pravovoi pomoshchi i pravovyh otnosheniiakh po grazhdanskim, semeinym $i$ ugolovnym delam : zakliuchena $v$ g. Minske 22.01.1993, vstupila v silu 19.05.1994, dlia Rossiyskoy Federatsii 10.12.1994 [The convention on legal aid and legal relations on civil, family and criminal cases : signed in Minsk 22.01.1993, came into force on 19.05.1994, for the Russian Federation on 10.12.1994].

Konventsiia Organizatsii Ob'edinennykh Natsiy o bor'be protiv nezakonnogo oborota narkoticheskikh sredstvi psikhotropnykh veshchestv: zakljuchena vg. Vene 20.12.1988 g. ratifitsirovana Postanovleniem Verkhovnogo Soveta SSSR ot 09.10.1990 № 1711-I [The convention of the United Nations on fight against illicit trafficking in narcotic drugs and psychotropic substances : signed in Vienna on 20.12.1988, confirmed by the resolution of the Supreme Soviet of the USSR].

Konventsiia protiv transnatsional'noy organizovannoy prestupnosti priniata $v$ g. N'iu-Yorke 15.11.2000 Rezoliutsiey 55/25 na 62-om plenarnom zasedanii 55-oj sessii General'noy Assamblei OON [The convention against a transnational organized crime adopted in New York by 15.11.2000 Resolution $55 / 25$ at the $62 \mathrm{nd}$ plenary session of the 55th session of the United Nations General Assembly]. Available at: http://www.consultant.ru.

Korenevskiy Iu.V. (1999). Actual problems of proving in a criminal process. State and right, (2), $55-62$.

Lugovik V.F. (2015). Codification as the way of improvement of legal regulation of operational search activity. Operativnik (syshchik), 1(42), 12-19.

O merakh po sovershenstvovaniiu sotrudnichestva po linii Interpola: Prikaz MVD RF ot 28.02.2000 № 221, utverzhdena Instruktsiia ob organizatsii informatsionnogo obespecheniia sotrudnichestva po linii Interpola [On measures for improvement of cooperation on the Interpol line: The order of the Ministry of Internal Affairs of the Russian Federation of 28.02.2000 No. 221, the Instruction of the organization of information support of cooperation on the Interpol line]. Available at: http://www. consultant.ru.

O politsii: Federal'nyi zakon ot 07.02.2011 № 3-FZ [On police: Federal law of 07.02.2011 No. 3-FZ]. Available at: http://www.consultant.ru.

$O b$ utverzhdenii Instruktsii o poriadke predstavleniia rezul'tatov operativno-rozysknoy deiatel'nosti organu doznaniia, sledovateliu ili v sud: Prikaz MVD Rossii № 776, Minoborony Rossii № 703, FSB Rossii № 509, FSO Rossii № 507, FTS Rossii № 1820, SVR Rossii № 42, FSIN Rossii № 535, FSKN Rossii № 398, SK Rossii № 68 ot 27.09.2013. [On the approval of the Instruction about an order of representation of results of operational search activity to the inquiry bodies, investigator or court: Order of the Ministry of Internal Affairs of Russia No. 776, Ministry of Defence of the Russian Federation No. 703, FSB of Russia No. 509, FSO of Russia No. 507, FCS of Russia No. 1820, SVR of Russia No. 42, FSIN of Russia No. 535, FSKN of Russia No. 398, SK of Russia No. 68 of 27.09.2013]. Rossijskaja gazeta, (282).

$\mathrm{Ob}$ utverzhdenii Instruktsii o poriadke provedeniia sotrudnikami organov vnutrennikh del Rossiyskoy Federatsii glasnogo operativno-rozysknogo meropriiatiia, obsledovanie pomeshchenii, zdanii, sooruzhenii, uchastkov mestnosti i transportnykh sredstv i Perechnia dolzhnostnykh lits organov 
vnutrennikh del Rossiiskoi Federatsii, upolnomochennykh izdavat' raspoiazheniia o provedenii glasnogo operativno-rozysknogo meropriiatiia, obsledovanie pomeshchenii, zdanii, sooruzhenii, uchastkov mestnosti i transportnykh sredstv: Prikaz MVD Rossii ot 01.04.2014 No 199.[On the approval of the Instruction about an order of carrying out overt operational search inspection of premises, buildings, structures, grounds and vehicles by law-enforcement officers of the Russian Federation and the list of law-enforcement officials of the Russian Federation authorized to issue instructions about carrying out overt operational search inspection of premises, buildings, structures, grounds and vehicles: Order of the Ministry of Internal Affairs of Russia of 01.04.2014 No. 199]. Available at: http:// www.consultant.ru.

Ob utverzhdenii Instruktsii po organizatsii informatsionnogo obespecheniia sotrudnichestva po linii Interpola: Prikaz MVD RF № 786, Minjusta RF № 310, FSB RF № 470, FSO RF № 454, FSKN RF № 333, FTS RF 971 ot 06.10.2006.[On the approval of the Instruction on the organization of information support of cooperation on the Interpol line: Order of the Ministry of Internal Affairs of the Russian Federation No. 786, Ministry of Justice of the Russian Federation No. 310, FSB of the Russian Federation No. 470, FSO of the Russian Federation No. 454, FDCS of the Russian Federation No. 333, FCS of Russia 971 of 06.10.2006]. Available at: http://www.consultant.ru.

Ob uchastii Rossiyskoy Federatsii v deiatel'nosti Mezhdunarodnoy organizatsii ugolovnoy politsii - Interpola: Ukaz Prezidenta RF ot 30.07.1996 No 1113. [On participation of the Russian Federation in the activities of International Criminal Police Organization - the Interpol: Decree of the President of the Russian Federation of 30.07.1996 No. 1113]. Available at: http://www.consultant. ru.

Perechen' ofitsial'no opublikovannykh mezhdunarodnykh dogovorov Rossiyskoy Federatsii, predusmatrivaiushchikh vozmozhnost' vydachi litsa dlia ugolovnogo presledovaniia, ispolneniia prigovora, a takzhe peredachi litsa, osuzhdennogo k lisheniiu svobody, dlia otbyvaniia nakazaniia $v$ gosudarstve, grazhdaninom kotorogo takoe litso iavliaetsia, vydacha inostrannomu gosudarstvu lits dlia osushchestvleniia ugolovnogo presledovaniia ili ispolneniia prigovora: prilozhenie $k$ Postanovleniiu Plenuma Verkhovnogo Suda RF ot 14.06.2012 No 11 "O praktike rassmotreniia sudami voprosov, sviazannykh s vydachei lits dlia ugolovnogo presledovaniia ili ispolneniia prigovora, a takzhe peredachei lits dlia otbyvaniia nakazaniia". [The list of officially published international treaties of the Russian Federation providing possibility of extradition of a person for criminal prosecution, execution of a sentence, and also transfer of a person sentenced to imprisonment for serving punishment in the state to which this citizen belongs, the extradition of persons to a foreign state for implementation of criminal prosecution or execution of a sentence: the annex to the Resolution of Plenum of the Supreme Court of the Russian Federation of 14.06.2012 No. 11 "On practice of consideration by courts the questions connected with extradition of persons for criminal prosecution or execution of a sentence, and also transfer of persons for serving punishment"].

Polozhenie o Federal'noy sluzhbe Rossiyskoy Federatsii po kontroliu za oborotom narkotikov, utverzhdeno Ukazom Prezidenta RF ot 28.07.2004 No 976 "Voprosy Federal'noy sluzhby Rossiyskoy Federatsii po kontroliu za oborotom narkotikov". [The provision on Federal Drug Control Service of the Russian Federation, approved by the Decree of the Russian President of 28.07.2004 No. 976 "The Issues of Federal Drug Control Service of the Russian Federation"]. Available at: http://www. consultant.ru. 
Poliakov M.P. Osnovy ugolovno-protsessual'noy interpretatsii rezul'tatov operativno-rozysknoy deiatel'nosti [The bases of criminal procedure interpretation of results of operational search activity]. Nizhny Novgorod: NA the Ministry of Internal Affairs of Russia, 2000. 114 p.

Poliakov M.P. Ugolovno-protsessual'naia interpretatsiia rezul'tatov operativno-rozysknoy deiatel'nosti: avtoref. dis [Criminal procedure interpretation of results of operational search activity: abstract of a thesis]. Nizhny Novgorod: Nizhny Novgorod Institute of Law of the RF Ministry of internal Affairs, 2002. $54 \mathrm{p}$.

Tkachuk T.A. Nauchno-tekhnicheskoe obespechenie rozysknoy deiatel'nosti v ugolovnom protsesse Rossii: diss. dokt. [Scientific and technical ensuring search activity in criminal procedure of Russia: doctoral thesis]. Vladimir: Vladimir Institute of Law of the Federal Penitentiary Service, 2011. $394 \mathrm{p}$.

Shumilov A.Iu. (2013). Operational search science in Russia in the Post-Soviet time (1992-2012): periodization, staged state and expected development directions. Operativnik (syshchik), 3 (36), 3-14.

\section{Современное состояние и проблемы}

\section{правового регулирования производства}

неотложного розыска по уголовным делам

И.А. Медведев,

Сибирский юридический институт ФСКН России (2. Красноярск)

Россия, 660131, Красноярск, ул. Рокоссовского, 20

В статье отмечается актуальность и малоисследованность правоведами и криминалистами вопросов розыска в безотлагательном порядке. Анализируется состояние действующего законодательства о производстве розыска, в том числе в неотложном порядке, с учетом иерархии системы российского законодательства. Обозначены проблемы правового регулирования неотложного розыска и обоснована необходимость самостоятельной нормативно-правовой регламентации данного вида розыска. Указывается на взаимосвязь уголовно-прочессуальной и оперативно-розыскной деятельности при проведении неотложного розыска, которая должна быть сбалансирована на законодательном уровне. Рассмотрены возможные варианты правовой регламентации неотложного розыска: ведомственного и межведомственного регулирования организачии порядка неотложного розыска. В иелях перспективного развития учения о розыске предложено систематизировать нормы, регулируюшие розыскную деятельность, в единый нормативно-правовой акт: федеральный закон о розыске с включением в него норм, предусматривающих основания, условия и порядок производства неотложного розыска.

Ключевые слова: неотложный розыск, правовое регулирование, оперативно-розыскная деятельность, уголовно-процессуальное законодательство, розыскные мероприятия, ведомственные и межведомственные инструкиии.

Научная специальность: 12.00.00 - юридические науки. 